\title{
Son Dönem Böbrek Yetmezliğinde Tıbbi Beslenme Tedavisi
}

\author{
Medical Nutrition Therapy in End-Stage Renal Failure
}

\section{Gül Kızıltan ${ }^{1}$}

Geliş tarihi/Received: 20.03.2018 • Kabul tarihi/Accepted: 18.12.2018

\section{ÖZET}

Kronik böbrek yetmezliği, pek çok etiyolojik neden ile ortaya çıkan, nefronların progresif ve geri dönüşümsüz kaybına bağlı glomerüler filtrasyon hızında ilerleyici azalmaya neden olan, kronik, kalıcı, ilerleyici bir durum olarak tanımlanır. Son dönem böbrek yetmezliği (SDBY) de kronik böbrek yetmezliğinin beşinci evresini ifade eder. SDBY’nin tedavisinde renal replasman tedavileri (hemodiyaliz, periton diyalizi, transplantasyon) uygulanmaktadır. Tüm bu tıbbi tedavi süreci içerisinde bireye özgü planlanan tıbbi beslenme tedavisi, komplikasyonların önlenmesi ve yaşam kalitesinin arttırılmasında büyük önem taşır. SDBY hastalarında tıbbi beslenme tedavisinin başlıca amacı, hastalığın ilerlemesinin yavaşlatılması veya önlenmesi, üremik toksisitenin azaltılması, nefron kaybının oluşturduğu sistemik komplikasyonların ve hastanın iştahının düzeltilmesi, uygun bir beslenmenin sağlanması, malnütrisyonun önlenmesi, sıvı elektrolit dengesizliklerinin engellenmesidir. Bu derlemede, güncel bilgiler ışı̆̆ında SDBY olan hastalarda tıbbi beslenme tedavi yaklaşımı tartışılmıştır.

Anahtar kelimeler: Son dönem böbrek yetmezliği, hemodiyaliz, periton diyalizi, tıbbi beslenme tedavisi

\begin{abstract}
Chronic renal failure is defined as a chronic, persistent, progressive condition that results from many etiological causes, leading to a progressive reduction in glomerular filtration rate due to the progressive and irreversible loss of nephrons. End stage renal failure (ESRD) refers to the fifth stage of chronic renal failure. Renal replacement therapies (hemodialysis, peritoneal dialysis, transplantation) are used in the treatment of ESRD. During these medical treatment processes, the individualized medical nutrition therapy planning is very important for the prevention of complications and improving the quality of life. The main aim of medical nutritional therapy in ESRD patients is to slow or prevent disease progression, to reduce uremic toxicity, to improve systemic complications caused by nephron loss and to improve patient appetite, to provide optimal nutrition, to prevent malnutrition, to prevent liquid electrolyte imbalances. In this review, medical nutrition therapy approach is discussed in patients with ESRD with current literature information.
\end{abstract}

Keywords: End stage renal failure, hemodialysis, peritoneal dialysis, medical nutrition therapy

\section{GİRIŞ}

Kronik böbrek yetmezliği (KBY), glomerüler tanımlanabilir. Kronik böbrek yetmezliği, hem filtrasyon hızında azalmanın sonucu, böbreğin sıvı- ülkemizde hem de tüm dünyada görülme sıklığı solüt dengesini ayarlama ve metabolik endokrin gittikçe artan önemli bir halk sağlığı sorunudur (1). işlevlerinde kronik ve ilerleyici bozulma hali olarak Önemli bir morbidite ve mortalite nedeni olan bu

1. İletişim/Correspondence: Başkent Üniversitesi, Sağlık Bilimleri Fakültesi, Beslenme ve Diyetetik Bölümü, Ankara, Türkiye • E-posta: gkizilta@baskent.edu.tr (1) https://orcid.org/0000-0001-5012-5838 
hastalık, düşük farkındalık nedeniyle Son Dönem Böbrek Yetmezliği (SDBY) evresine ilerlemekte, yüksek tedavi maliyeti nedeniyle ülkeler için büyük bir ekonomik yük oluşturmaktadır (2). Türkiye'de Kronik Böbrek Hastalığı Prevalans araştırması amacıyla yapılan CREDIT (Chronic Renal Disease in Turkey) çalışması sonuçlarına göre, ülkemizde genel erişkin popülasyonda kronik böbrek hasarı prevalansının \%15.7 olduğu saptanmış, yaşla birlikte riskin belirgin bir şekilde arttı̆̆ı, kırsal kesimde yaşayanlarda riskin daha fazla olduğu bildirilmiştir (3).

$\mathrm{Bu}$ derlemede, hem dünyada hem de ülkemizde prevalansı yüksek ve farkındalığı düşük olan Son Dönem Böbrek Yetmezliği'ne sahip hastalara tıbbi tedavinin yanında uygulanan tıbbi beslenme tedavi yaklaşımının güncel bilgiler ışığında tartışılması amaçlanmıştır.

\section{Son Dönem Böbrek Yetmezliği}

Kronik böbrek hastalığının erken tanısının önündeki engellerden bir tanesinin hastalığın ve evrelerinin doğru tanımlanamaması olduğu düşünülmektedir. 2002'de Amerika Birleşik Devletleri’nde Ulusal Böbrek Vakfı'nın Böbrek Hastalığı Sonuçları Kalite Girişimi (NKF/KDOQI / National Kidney Foundation Kidney Disease Outcomes Quality Initiative) tarafindan yayınlanan Kronik Böbrek Hastalığı Klinik Uygulama Kılavuzu'nda kronik böbrek hastalı̆̆ı, yapısal ya da işlevsel bozukluklarla birlikte kendini gösteren böbrek hasarı ya da 3 ay veya daha uzun süre böbrek işlevlerinde azalma (glomerüler filtrasyon hızı <60 $\mathrm{mL} /$ dakika/1.73 $\mathrm{m}^{2}$ ) olarak tanımlanmaktadır (4). Glomerüler filtrasyon hızı (GFH), böbrek işlevlerinin en iyi ölçütlerinden birisidir. GFH yaşa, cinsiyete ve vücut ölçülerine göre değişkenlik göstermekle birlikte genç erişkinlerde normal değer yaklaşık 120-130 mL/ dakika/1.73 m²'dir. Kronik böbrek hastalığı olanlarda hastalığın evresi, tanı dikkate alınmaksızın K/DOQI KBH sinıflanmasına göre saptanan böbrek işlev düzeyine dayanarak belirlenmelidir (5) (Tablo 1).
Tablo 1. Kronik böbrek hastalığı evreleri ve GFH değerleri

\begin{tabular}{lll}
\hline Evre & Tanımlama & $\begin{array}{l}\text { GFH }(\mathbf{m L} / \\
\left.\text { dakika/1.73 } \mathbf{~ m}^{\mathbf{2}}\right)\end{array}$ \\
\hline 1 & Böbrek hasarı ve normal GFH & $\geq 90$ \\
2 & Böbrek hasarı ve hafif GFH & $60-89$ \\
3 & Orta derece GFH & $30-59$ \\
4 & Ağır derecede GFH & $15-29$ \\
5 & Böbrek yetmezliği & $<15$ (veya diyaliz) \\
\hline
\end{tabular}

KBY oluşumu ve gelişiminde birçok etmen sorumlu olmakla birlikte aynı hastada farklı nedenler birlikte görülebilmektedir (6). Bu risk etmenleri ileri yaş, ailede KBH öyküsü, böbrek kütlesinde azalma, düşük doğum ağırlığı, ırk, düşük sosyo-ekonomik durum, düşük eğitim düzeyi, diyabet, hipertansiyon, otoimmün hastalıklar, sistemik enfeksiyonlar, üriner enfeksiyonlar, üriner sistem taşları, üriner sistem obstrüksiyonu, proteinüri, kötü glisemik kontrol, obezite, dislipidemi, sigara içme, ilaç toksisitesi sayllabilir (7).

Türkiye'de de Sağlık Bakanlığı ve Türk Nefroloji Derneği (TND)'nin 2017 yllı ortak raporunda yer alan verilere göre, SDBY'nin en önemli etiyolojik etmenleri arasinda hem hemodiyaliz (HD) hem de periton diyalizine (PD) giren hastalar için diyabet (sırasıyla $\% 38.1$ ve \%27.9), hipertansiyon (sirasıyla \%27.5 ve \%27) ve kronik glomerülonefrit (sirasıyla \%6.01 ve \%12.3) ilk sıralarda yer almaktadır (8).

Hastaların klinik semptom ve bulguları böbrek yetmezliğinin derecesi ve gelişme hızı ile yakından ilişkilidir. GFH 35-50 mL/dakikanın altına inmedikçe hastalar semptomsuz olabilir. Hastaların ilk semptomları genellikle noktüri ve anemiye bağlı halsizliktir. GFH 20-25 mL/dakika olunca hastada üremik semptomlar ortaya çlkmaya başlar (9). Hastalarda, hipernatremi, hipokalsemi, hiperpotasemi, hiperfosfatemi, ödeme bağlı anüri veya oligüri, total protein turnoverında ve kas protein sentezinde azalma, katabolizmasinda artma, hipertansyon, hiperlipidemi, kas krampları, bulantı, kusma, anemi, deride kaşıntı gibi önemli bulgular ve komplikasyonlar görülür. 
GFH'nin <15 mL/dakika'nın altında olması son dönem böbrek yetmezliği (SDBY) olarak tanımlanır. Hastalığın başlangıcında ilaç ve diyet tedavisi yeterli olsa da, böbrekler tümüyle görevini yapamaz duruma geldiğinde yani koruyucu tedavi ile üremik belirti ve bulguların kontrol edilemediği hastalarda renal replasman tedavisi (RRT) yapılmaktadır. Renal replasman tedavileri diyaliz (hemodiyaliz ve periton diyalizi) ve böbrek transplantasyonunu kapsar (10). 2017 yılı içinde ilk kez RRT’ne başlayan hastaların (çocuk hastalar dahil) uygulanan RRT tipine göre dağılımı (genel insidans) \%81.7 hemodiyaliz, \%7.4 periton diyalizi, \%10.9 transplantasyon olarak belirlenirken, 2017 yılı sonu itibarıyla kronik HD/PD programinda veya fonksiyonel greftle izlenmekte olan tüm hastaların (çocuk hastalar dahil) RRT tipine göre dağılımı (genel prevalans) ise, \%75.8 hemodiyaliz, \%4.3 periton diyalizi ve \%19.8 transplantasyon olarak rapor edilmiştir (8).

Kronik böbrek hastalığının ilerlemesi ile birlikte beslenme ve metabolik sorunlar sık karşılaşılan durumdur. Özellikle kronik böbrek yetmezliği olan Evre 4-5 hastalarda, metabolik değişimler sonucunda protein katobolizması artmakta ve kas kütlesi ile toplam vücut protein miktarında azalma meydana gelmektedir. Sonuçta gelişen beslenme bozukluğu birçok etmene bağlı olup "üremik malnütrisyon” olarak adlandırılmaktadır. Üremiyle beraber anabolik hormonların aktivitesi (insülin, insülin benzeri büyüme faktörü-1) azalıp, katabolik hormonlar (kortizol, glukagon) artmaktadır. Üremik toksinlerin vücutta birikimi, inflamasyon ve inflamatuvar sitokinlerin artması sonucunda, hastalarda protein ve enerji alımı azalmaktadır. Bütün bunlara ek olarak yapılan diyette kontrolsüz protein kısıtlaması da malnütrisyona yatkınlığı daha da arttırmaktadır (11).

Son dönem böbrek yetmezliği olan hastalarda malnütrisyonun bir göstergesi olan serum albümin düzeyleri düşük $(<3.5 \mathrm{~g} / \mathrm{dL})$ olan hemodiyaliz hastalarının sıklığı \%12.88 iken sürekli ayaktan periton diyalizi olan hastaların sıklığı ise \%26.2 olarak bildirilmiştir (8). Malnütrisyonun SAPD ve HD uygulanan hastalarda morbidite ve mortalitenin önemli belirleyicisi olduğu düşünülmektedir. Kronik böbrek yetmezliğinde pek çok nedenle malnütrisyon gelişebilmektedir. Hastaların malnütrisyon derecelerine göre yaşam kaliteleri de bozulmaktadır. Malnütrisyon tedavi edildiğinde, hastaların yaşam kalitesi iyileştirilebilmektedir. Kronik böbrek yetmezliği olan hastalarda malnütrisyona neden olan ve beslenmeyi etkileyen birbiri ile ilişkili birçok etmen vardır (12).

\section{Tibbi Beslenme Tedavisi}

Kronik böbrek yetmezliğinin erken ve geç dönemlerinde uygulanan tıbbi beslenme tedavisinin hastalığın sürecini etkilediği bildirilmiştir. Kronik böbrek yetmezliği olan hastaların tıbbi beslenme tedavisi önerileri farklılık göstermesiyle birlikte en yaygin kullanılan beslenme kllavuzu, Amerika Birleşik Devletleri'nde Ulusal Böbrek Vakfı'nın Böbrek Hastalığı Sonuçları Kalite Girişimi (NKF/ KDOQI) ve Avrupa Parenteral ve Enteral Nütrisyon Derneği (European Society for Parenteral and Enteral Nutrition / ESPEN) ile Avrupa Böbrek Birliği/Avrupa Diyaliz ve Transplantasyon Birliği'nin Avrupa En İyi Uygulama Kılavuzları (European Renal Association/ European Dialysis and Transplant AssociationEuropean Best Practice Guidelines /ERA/EDTA Council EBPG Guideline) önerileridir (13-15).

SDBY hastalarında tıbbi beslenme tedavisinin başlıca amacı, hastalığın ilerlemesinin yavaşlatılması veya önlenmesi, üremik toksisitenin azaltılması, nefron kaybının oluşturduğu sistemik komplikasyonların ve hastanın iştahının düzeltilmesi, uygun bir beslenmenin sağlanması, malnütrisyonun önlenmesi, sıvı elektrolit dengesizliklerinin engellenmesidir.

\section{Enerji}

KBY hastalarında doku yıkımının önlenmesi ve pozitif azot dengesinin sürdürülebilmesi için yeterli enerji alımı gerekmektedir (16). Sedanter yaşayan, 
obez olmayan hastalarda diyalizattan emilen glukoz da dahil enerji gereksinmeleri NKF-KDOQI’ya göre 60 yaş altı 35 kkal/kg/gün, 60 yaş üzeri 30-35 kkal/kg/ gün olarak önerilmektedir (17). Hafif şişman, şişman ya da beslenme yetersizliği olan hastalarda enerji planlamasında bireysel düzenlemeler gereklidir. ESPEN'e göre de benzer şekilde enerji gereksinme önerileri 30-35 kkal/kg/gün olarak verilmiştir (18).

\section{Protein}

Tıbbi beslenme tedavi programında KBY hastasının böbrek işlevleri göz önünde bulundurularak, protein kısıtlamasının yapılması ve alınan proteinin yüksek biyolojik değere sahip olmasına dikkat edilmesi gerekmektedir. Diğer taraftan organizmanın gereksinmesinden daha az protein tüketilmesi malnütrisyon gelişimine ve böbrek hasarının ilerlemesine neden olacağı da göz önünde bulundurulmalıdır (19). Hemodiyaliz ve periton diyaliz anında sırasıyla diyaliz sıvısıyla protein, aminoasit ve peptid kayıpları olmaktadır. Kaybedilen aminoasitlerin negatif azot dengesi oluşturmaması için yerine konulması gereklidir. Diyet proteini, NKFKDOQI ve diğer kılavuzlara göre hemodiyaliz ve periton diyaliz hastalarında sırasıyla 1.0-1.2 g/kg/gün ve 1.2-1.4 g/kg/gün olarak ayarlanması gereklidir (13).

\section{Karbonhidrat}

Kronik böbrek yetmezliğinde glukoz metabolizması ve insülin direncinin bozulması, artmış hepatik glikoneogenez ile birleşince glukoz ve üre düzeyinin yükselmesiyle sonuçlanır. Üremide bazal insülin salgısı azalır, glukoz infüzyonuna yanıt sınırlıdır. Diyaliz hastalarında aşırı karbonhidrat alımı, hipertrigliseridemi ve hiperglisemiye neden olup morbiditeyi arttırabilir. Periton ve hemodiyaliz hastalarında diyet enerjisinin \%50-60’ı karbonhidratlardan gelmeli, basit karbonhidratların yerine kompleks karbonhidratların alınması sağlanmalıdır (13).

\section{Yağ}

Kronik böbrek yetmezliğinde diyalize giren hastalarda lipit metabolizmasındaki en sık karşılaşılan değişiklik lipolizin bozulmasıdır. Lipolizdeki azalma intestinal yağ emilimindeki gecikme ile birleşirse plazma trigliserit düzeyi yükselebilir (20). Genel olarak HD hastalarında hipertrigliseridemi, bir kısmında ise hipertrigliseridemi ve kolesterol düzeylerinde bozukluklar görülmektedir. Hemodiyaliz tedavisi sırasında ekstraselüler sıvıdan karnitin uzaklaşmakta ve karnitin yetersizliği de uzun zincirli yağ asitlerinin oksidasyonunun bozulmasına neden olmaktadır (21). SAPD hastalarında da hiperlipidemi sıklıkla görülmektedir. Bu bozukluklar, diyaliz hastalarında ateroskleroz ve kardiyovasküler hastalık insidansını arttırmaktadır (22). Tüm bu nedenlere bağlı olarak diyaliz hastalarında, toplam enerjinin \%30-35'inin yağdan karşılanması, diyetle kolesterol alımının 200 mg/gün’ün altına indirilmesi önerilmektedir (13).

\section{Mineraller, Vitaminler ve Sıvı Sodyum (Na)}

İki hemodiyaliz arasında kazanılan vücut ağırlığının 1.5-2 kg’ı aşmaması önerilmektedir. Sağlıklı bir kişi günlük olarak $2.3 \mathrm{~g}$ ile $6.9 \mathrm{~g}$ kadar sodyum almaktadır. Hemodiyaliz hastalarında günlük çıkarılan idrar miktarı ile sodyum dengesi arasındaki ilişkiye bağlı olarak sodyum kısıtlaması düzenlenmektedir. Günlük idrar miktarı yaklaşık $1000 \mathrm{~mL}$ olan hastalarda hafif sodyum kısıtlaması 3-4 g yeterli olmasına karşılık anürik hastalarda sodyum alımı günde 1-2 g’a kadar düşürülmektedir. Hastanın çıkardığı her bir litre idrar miktarı için 2 g sodyum alması mümkün olmaktadır (23). Günlük 1-2 g sodyum dengesinin sağlanması amacıyla genellikle tuz ve salamura, turşu, ev salçası, konserve gibi tuz içeriği fazla olan yiyecekler diyetten çıkarılmaktadır. Sodyum kısıtlaması kararı için her hastanın ayrı ayrı değerlendirilmesi, ödem, kan basıncı, nefes darlığı gibi belirtilerin göz önünde bulundurulması gerekmektedir $(24,25)$. Hastalarda hipertansiyon veya kalp yetmezliği varsa, tuz ve su kısıtlaması daha dikkatli yapılmalıdır (26). 
Sodyum dengesi, genellikle SAPD hastalarinda HD’ye göre daha iyi kontrol edilebilmektedir. SAPD tedavisi ile günde 3-4 g sodyum diyaliz ile temizlenebilmektedir. Hipertonik solüsyonların fazla kullanıldığı durumlarda, bu miktar 6-8 g’a yükselmektedir. Yüksek dekstrozlu solüsyonların kullanımı kontreendike değilse, anürik SAPD hastasında sodyum alımı 3-4 g/gün, sıvı alımı ise 750 $\mathrm{mL}+$ bir günde çıkardığı idrar miktarı veya 2-2.5 L olmalıdır (27).

\section{Potasyum (K)}

Vücudaalınanpotasyumunyaklaşık\%10’ubağırsaklar, kalanı da böbrek yolu ile kaybedilmektedir. Hemodiyaliz hastalarının günlük potasyum gereksinmesi bireysel olarak değerlendirilerek, idrar çıkışı olan hastalarda hafif bir potasyum sınırlaması yapılmaktadır. Her 1 litre idrar çıkışı için 2 g potasyum alımı mümkün olabilmektedir. Anürik hemodiyaliz hastalarında günlük potasyum alımı 40-70 mEq (1600-2000 mg) olacak şekilde kısıtlanmaktadır. Hemodiyaliz tedavisi serum potasyum düzeyini, periton diyalizine göre daha hızlı düşürmektedir. Periton diyalizi, serum potasyum düzeyinde yavaş bir düşüş istendiğinde kullanılmaktadır. Ancak belirgin derecede rezidüel idrar miktarı olan HD hastalarında sadece hafif bir potasyum kısıtlaması yeterlidir. Şiddetli kusma, diüretik kullanımı veya diyare nedeniyle potasyum kayba uğrayabilmekte ve hipokalemi gelişebilmektedir. Bu durumda da diyetin potasyum içeriği arttırılmalıdır (28).

SAPD uygulanan hastalarda potasyum gereksinmesi ayrı ayrı ele alınmalıdır. Alınan potasyumun yaklaşık \%30’u kadar bağırsaklar, geri kalanı da böbrekler ve diyalizat yolu ile kaybedilir. Tedavinin sürekli olması nedeniyle SAPD hastalarının haftalık potasyum klirenslerinin, HD hastalarına göre daha fazla olduğu hesaplanmış ve hiperkalemi riski HD hastalarından daha düşükgörülmüştür. SAPD hastalarında potasyum alımı normal potasyum düzeylerini sürdürecek yani günde yaklaşık $3000 \mathrm{mg}$ olacak şeklide ayarlanmalıdır (29). Diğer taraftan diyetine uymayan hastalarda hiperpotasemi hayatı tehdit edebilmektedir (30).

\section{Kalsiyum-Fosfor (Ca-P)}

Fosforun renal atımdaki yetersizliği, GFH ile yakından ilişkilidir. Normalde $120 \mathrm{~mL} /$ dakika olan GFH'nın, $25 \mathrm{~mL} /$ dakika’ya düştüğü dönemde plazmada fosfor birikimi çok belirgin olarak gözlenmektedir. Tübüler fosfor atımındaki yetersizlik, hastalarda renal osteodistrofi olarak tanımlanan değişikliklerin ortaya çlkmasına neden olmaktadır. Renal osteodistrofide fosforun yeterli düzeyde atılamaması nedeniyle plazma fosfor düzeyleri yükselmiş, buna ikincil olarak kalsiyum düzeyinin düşmesi eklenmiştir ve sekonder olarak paratroid hormon düzeyi artmıştır (31,32). Hemodiyaliz hastalarında serum fosfor düzeyini 2.5-4.5 mg/dL arasında tutmak için fosfor alımı 800-1200 mg/gün olacak şekilde kısıtlanmaktadır. Hemodiyaliz hastalarında da diyetle alınan fosforun gastrointestinal sistemden emiliminin yaklaşık \%80 civarında olması, fosfor bağlayıcı ajanların kullanmasını gerektirmektedir (33). Periton diyaliz hastalarında, molekül yapısı ve elektrik yükü nedeni ile fosforun peritoneal diyaliz de serbest klirensi oldukça kısıtlıdır. Bu hastalara önerilen miktardaki proteinli bir diyette fosforu 1200 mg'ın altına düşürmek pek mümkün olmamakta ve besinlerdeki fosforun sadece \%50'si emilmekte, bu nedenle HD hastalarında olduğu gibi fosfor bağlayıcı ilaçlara çoğu zaman gerek duyulmaktadır (34).

HD hastalarında fosfor yüksekliği, aktif D vitamininin azalması sonucu bağırsaklardan kalsiyum emiliminin azalması gibi nedenlerle kalsiyum gereksinmesi artmaktadır. Kalsiyumun 1.0-1.5 g/gün alınması günlük gereksinmeyi karşılamaktadır. Hipokalsemi durumunda hiperparatroidizm gelişmekte ve renal osteodistrofiye neden olmaktadır. Fosfor bağlayıcı olarak kullanılan kalsiyum tuzlarının içerdiği kalsiyumun \%25 kadarınınbağırsakyoluileemiliminin sağlanması için bu ilaçların öğün aralarında kullanılması gerekmektedir. Negatif kalsiyum dengesini düzeltmek amacı ile $\mathrm{D}$ vitamini tedavisi 
de uygulanmalıdır. Günlük 300-500 mg kalsiyum içeren diyet ile birlikte alınan kalsiyum eklenmesine erken dönemde başlanması hiperparatiroidizmin önlenmesinde yarar sağlamaktadır (35).

HD tedavisi alan bireylerde fosfor düzeyi 4.5-5.5 mg/ $\mathrm{dL}$ arasında tutulması hedeflenmektedir. Hastalarda renal osteodistrofinin engellenmesi için günlük fosfor alımının 1000 mg’n altında olması gerekmektedir. Ancak HD hastalarında yeterli protein diyetinin sağlanması amacıyla fosfor alımı günde 1200 mg’ın altına düşürülememektedir. Fosfor dengesi genellikle fosfor bağlayıcı ilaçların kullanılması aracılığı ile sağlanmaktadır. Aynı zamanda KBY'de fosforun yeteri kadar atılamaması sonucunda serum fosfor düzeyinin yükselmesi, serum kalsiyum düzeyinin düşmesine neden olmaktadır (19,36,37).

Diyaliz hastalarında, protein ve fosfor kısıtlaması, iştahsızlık ve D vitamini eksikliği kalsiyum gereksinmesini arttırmaktadır. Serum kalsiyum düzeyinde düşme, PTH salgılanmasını uyararak, plazma PTH düzeyinin artmasına neden olmaktadır. Kalsiyum desteği ve serum fosfor düzeyinin kontrolü, kalsiyum içeren fosfor bağlayıcı ajanlar kullanılmak suretiyle, eş zamanlı olarak gerçekleştirilmektedir (38).

\section{Vitaminler}

Kötü beslenme nedeniyle alım yetersizliği, suda-çözünür vitaminlerden zengin olan yiyeceklerin potasyumdam zengin oluşu nedeniyle sınırlandırılması, üremi nedeniyle oluşan metabolik bozukluklar, ilaçlar tarafindan emiliminin engellenmesi, enfeksiyon, gastrointestinal hastalıklar gibi eşlik eden diğer hastalıklar veya komplikasyonlar nedeniyle vitamin içeren besinlerin alımının azalması, SAPD'de diyalizat yolu ile ve hemodiyaliz sırasında oluşan kayıplar diyaliz hastalarında vitamin ve mineral yetersizliğine yol açmaktadır (39). İdame diyaliz hastalarında (hem HD hem SAPD tedavisi görenlerde) genelde $B_{6}$ vitamini, folik asit ve $C$ vitamininde yetersizlikler görülmektedir. $B_{6}$ vitamini yetersizliği, aminoasit kullanımında ve lipit metabolizmasında bir koenzim olarak rol oynaması nedeniyle özellikle kritiktir. Folik asit, $\mathrm{B}_{6}$ vitamini, $\mathrm{B}_{12}$ vitamini bir seri metabolik yolda birlikte çalıştıkları için birinin yetersizliği diğerlerini etkiler (40). Ancak, serum retinol bağlayıcı protein düzeylerinin artması, böbrekte yıkımının azalması ve diyaliz tedavisi ile A vitamininuzaklaştırılamamasınedeniyle, hemodiyaliz veperiton diyalizhastalarında serum A vitamini düzeyi artmıştır. Bu nedenle A vitamini içeren preperatların kullanılmasının sakıncalı olduğu vurgulanmaktadır. Diyaliz hastalarında A hipervitaminozu anemiye, lipit ve kalsiyum metabolizması bozukluklarına da neden olabilmektedir (41). Diğer taraftan böbrek hastalarında bazı eser elementlerin vücuttaki miktarının yeterli olup olmadığını belirlemek güçtür. Ancak, demir, kalsiyum ve çinko eksikliklerinin diyaliz hastalarında görülebildiği belirtilmektedir. Diyaliz hastalarında demir yetersizliğiyle böylece anemi ile sık karşılaşılabilmektedir. Çünkü bağırsaklardan emilen demir miktarı azalabilmekte, ciddi kan kayıpları ile karşılaşılabilmekte ve demir diyaliz membranına bağlanabilmektedir. Hastanın serum ferritin ve demir düzeylerine bakılarak demir eklemesi önerilmektedir. Anemi tedavisi için günümüzde insan EPO (eritropoietin) kullanilmakta yani hastalara intravenöz demir tedavisi uygulanmaktadır (42).

\section{Sivı}

Hastanın ultrafiltrasyon miktarı ve rezidüel idrar miktarları hesaplanarak sıvı alımı düzenlenmelidir. Günlük ortalama 1000 mL ve günlük idrar çıkış miktarının toplamı, günlük alınacak sıvı miktarı olarak belirlenmektedir ve kuru ağırlığın \%3’ünü geçmemelidir (43). Sıvı alımı ifadesi gün içinde alınan su, ıhlamur, süt, çorba gibi tüm sıvıları içermektedir. Hipervolemi belirtileri varsa tuz ve sıvı alımında kısıtlamaya gidilmelidir. Anürik hastalarda günlük sıvı alımı 1000 mL'yi geçmemeli ve iki diyaliz seansı arası alınacak ağırlık günde $1 \mathrm{~kg}$ ile sinırlandırılmalıdır. Hemodiyaliz tedavisi alan bireylerde interdiyalitik vücut ağırlık kazanımı 2.5 kg olarak önerilmektedir (44). Fazla sıvı tüketilmesi yetersiz diyaliz sonucunda hastada toksik maddelerin 
birikimine buna bağlı olarak morbidite ve mortalite artışına neden olmaktadır (45).

\section{Transplantasyon Hastalarında Beslenme}

Transplantasyon hastalarında, transplantasyon öncesi ve sonrası dönemler olmak üzere biyokimyasal parametreler, antropometrik ölçümler, beslenme öyküsü, subjektif yöntemler, biyofizik yöntemler gibi çeşitli parametreleri içeren geniş kapsamlı nütrisyonel değerlendirmelerin yapılması çok önemlidir (46).

Pre-op dönemde, nütrisyonel gereksinmeler hastaya özel, bireysel olarak belirlenmelidir. Protein gereksinmesi, transplantasyon öncesi idame durumlarında 0.8-1.2 g/kg/gün, replasyonda 1.3-2 g/ $\mathrm{kg} /$ gün olarak önerilmektedir. Enerji gereksinmesi, 30-35 kkal/kg veya bazal metabolizma hızı×1.2-1.3 olacak şekilde değerlendirilmelidir. Sodyum ve sıvı gereksinmesi kısıtlamaları organ yetmezliği semptomlarının iyileştirilmesi için gerekli olabilir. Diyet sodyum kısitlamasıyla sıvı retansiyonu sağlanabilir. Transplantasyon öncesi diyet, çoğunlukla azar azar sık sık verilen, besin değerleri yüksek, küçük öğünlerden oluşacak şekilde planlanmalıdır (47). Post-op dönemde ise, hastaların enerji gereksinmeleri bu dönemde cerrahi müdahale faktörü ve immünosupresif tedavinin etkisi de dikkate alınarak 30-35 kkal/kg/gün olarak önerilmektedir. Postoperatif akut dönemde yetersiz düzeyde fiziksel aktivite ve transplantasyon sonrası diyetin açılmasıyla beraber obezite riskinin arttığı görülmüştür. Obez bireyler için önerilen enerji alımı $25 \mathrm{kkal} / \mathrm{kg} /$ gün olarak belirlenmiştir. Akut dönemde toplam enerjinin \%5055’i karbonhidrat ve \%30-35'i yağdan gelecek şekilde düzenlenmesi önerilmektedir (48). Bireylerin sıvı gereksinmesinde böbrek işlev durumu ve çıkarılan idrar miktarı dikkate alınarak belirlenmelidir. Ödem ve kan basıncı kontrolü amacıyla genellikle sodyum kısitlamasına gidilir. Ortalama sodyum kısitlaması 2-3 mg/gün olarak önerilmektedir. Vitamin ve mineral gereksinmelerinde ise, serum düzeylerine göre karar verilmelidir.

\section{SONUÇ VE ÖNERILER}

Sonuç olarak, kronik böbrek yetmezliği olan ve son evrede bulunan hastalara aldıkları tıbbi tedavinin yanı sira uygulanan renal replasman tedavi yöntemine uygun ve bireyselleştirilmiş tıbbi beslenme tedavi planı ile hastaların hem uygun düzeyde beslenmeleri sağlanırken hem de yaşam kalite düzeylerinin ve sağ kalımlarının arttırılmasına katkı sağlanacaktır.

Çıkar çatışması - Conflict of interest: Yazarlar çıkar çatışması olmadığını beyan ederler. - The authors declare that they have no conflict of interest.

\section{KAYNAKLAR}

1. Tokgöz, B. Kronik böbrek yetmezliğinde etiyoloji. Turkiye Klinikleri J Int Med Sci 2005;1(21):9-10.

2. T.C Sağlık Bakanlığı. Türkiye Böbrek Hastalıkları Önleme ve Kontrol Programı (2014-2017). Erişim: http://www. tsn.org.tr/pdf/Turkiye_Bobrek_Hastaliklari_Onleme_ve_ Kontrol_Programi.pdf Erişim tarihi: 27.05.2016.

3. Süleymanlar G, Utaş C, Arınsoy T, Ateş K, Altun B, Altiparmak MR, et al. A population based survey of chronic renal disease in Turkey - The CREDIT study. Nephrol Dial Transplant 2011;26:1862-71.

4. National Kidney Foundation. K/DOQI Clinical Practice Guidelines For Chronic Kidney Disease: evaluation, classification and stratification. Am J Kidney Dis 2002;39(2 Suppl 1):1-266.

5. Mahon A, Jenkins K. Chronic Kidney Disease Interest Group (Evre-1-3), EDTNA/ERCA, European Dialysis and Transplant Nurses Association/European Renal Care Association; İsviçre, 2007. p. 36-7.

6. Arık N, Ateş K, Süleymanlar G, Tonbul HZ, Türk S, Yıldız A. Hekimler İçin Hemodiyaliz Kaynak Kitabı. Ankara: Güneş Tıp Kitapevleri; 2009.

7. Akpolat T, Utaş C, Süleymanlar G. Nefroloji El Kitabı. 4. Baskı, İstanbul: Nobel Tip Kitapevleri; 2007.

8. Süleymanlar G, Ateş K, Seyahi N. Türkiye'de Nefroloji, Diyaliz ve Transplantasyon Registry Raporları. Türk Nefroloji Derneği (TND)Yayınları. Erişim: http://www. tsn.org.tr/. Erişim tarihi: 27.01.2019.

9. Tanrıverdi MH, Karadağ A, Hatipoğlu EŞ. Kronik böbrek yetmezliği. Konuralp Tip Dergisi 2010;2(2):27-32.

10. Özbaş N, Alibaz-Öner F, Altunoglu E. Kronik renal yetersizlikte etiyoloji ve yatış nedenlerinin irdelenmesi. İstanbul Tip Dergisi 2006;4:20-22. 
11. Pupim LB, İkizler TA. Uremic malnutrition: new insights into an old problem. Semin Dial 2003;16(3):224-32.

12. Daugirdas JT, Ing TS. Diyaliz El Kitabı. 2. Baskı. Ankara: Nobel Tip Kitapevleri; 1997.

13. Kopple J. K/DOQI clinical practice guidelines for nutrition for chronic dialysis patients. Am J Kidney Dis 2001;37(1):66-70.

14. Fouque D, Vennegoor M, Wee PT. EBPG Guideline on Nutrition. Nephrol Dial Transplant 2007;22(Suppl 2):4587.

15. Cano NJM, Aparicio M, Brunori G, Carrero JJ. ESPEN Guidelines for adult parenteral nutrition. Clin Nutr 2009;28: 359479.

16. Bergstrom J. Nutritional requirements of hemodialysis patients. In: Mitch W, Klahr S, editors. Nutrition and Kidney. 2nd ed. USA: Little, Brown and Company; 1993. p. 263-93.

17. Kopple JD. The national kidney foundation K/DOQI clinical practice guidelines for nutrition in chronic renal failure. Am J Kidney Dis 2002;40(1):68-73.

18. Cano N, Fiaccadori E, Tesinsky P, Toigi G, Drumbl W. ESPEN guidelines on enteral nutrition: Adult renal failure. Clin Nutr 2006;25: 295-310.

19. Ko GJ, Obi Y, Tortorici AY, Kalantar-Zadeh K. Dietary protein intake and chronic kidney disease. Curr Opin Clin Nutr Metab Care 2017;20(1):77-85.

20. Bellinghieri G, Santoro D, Calvani M, Mallamace A, Savica V. Carnitine and hemodialysis. Am J Kidney Dis 2003;41(3Suppl1):116-22.

21. Helal I, Smaoui W, Hamida FB, Ouniss M, Aderrahim $\mathrm{E}$, Hedri $\mathrm{H}$, et al. Cardiovascular risk factors in hemodialysis and peritoneal dialysis patients. Saudi J Kidney Dis Transpl 2010;21(1):59-62.

22. Kasiske B, Wheeler D. KDIGO 2012 clinical practice guideline for the evaluation and management of chronic kidney disease. Kidney International Supplement 2013;3:1-150.

23. Kaymak AD. Hemodiyaliz Hastalarının Yaşam Kalitesi ve Beslenme Durumlarının Değerlendirilmesi. T.C. Trakya Üniversitesi Sağlık Bilimleri Enstitüsü İç Hastalıkları Hemşireliği, Yüksek Lisans Tezi, Edirne, 2012.

24. Jain N, Reilly RF. Effects of dietary interventions on incidence and progression of CKD. Nat Rev Nephrol 2014;10(12):712-24.

25. Maduell F, Navarro V. Dietary salt intake and blood pressure control in haemodialysis patients. Nephrol Dial Transplant 2000;15:2063.

26. Mailloux LU. The overlooked role of salt restriction in dialysis patients. Semin Dial 2000;13:150-1.
27. Choi HY, Ha KS. Potassium balances in maintenance hemodialysis. Electrolyte Blood Press 2013;11(1):9-16.

28. Yu HL, Lu XH, Su CY, Tang W, Wang T. Potassium metabolism in continuous ambulatory peritoneal dialysis patients. Ren Fail 2014;36(5):748-54.

29. Karadakovan A, Kaymakçı Ş. Üriner sistem hastalıkları. Karadakovan A, Eti Aslan F, editör. Dahili ve Cerrahi Hastalıklarda Bakım. Geliştirilmiş 3. Baskı. Ankara: Akademisyen Tip Kitabevi; 2014. s. 859-916.

30. Goodman WG. Calcium and phosphorus metabolism in patients who have chronic kidney disease. Med Clin North Am 2005;89(3):631-47.

31. Tomasello S. Secondary hyperparathyroidism and chronic kidney disease. Diabetes Spectrum 2008;21(1):19-25.

32. Isakova T, Gutiérrez OM, Chang Y, Shah A, Tamez H, Smith K, et al. Phosphorus binders and survival on hemodialysis. J Am Soc Nephrol 2009;20(2):388-96.

33. Martín-del-Campo F, Batis-Ruvalcaba C, GonzálezEspinoza L, Rojas Campos E, Angel JR, Ruiz N, et al. Dietary micronutrient intake in peritoneal dialysis patients: relationship with nutrition and inflammation status. Perit Dial Int 2012;32(2): 183-91.

34. Komaba H, Tanaka M, Fukagawa M. Treatment of chronic kidney disease-mineral and bone disorder (CKD-MBD). Inter Med 2008; 47: 989-94.

35. Yıldız E. T.C. Sağlık Bakanlığı. Kronik böbrek yetmezliği ve beslenme. Ankara: Klasmat Matbaacıllk; 2008. s. 1-16.

36. Kaçar G. Kronik Böbrek Yetmezliği ve Bakım. In: Durna Z, editör. Kronik Hastalıklar ve Bakım. İstanbul: Nobel Tip Kitabevleri; 2012. s. 381-96.

37. Toussaint N, Cooney P, Kerr PG. Review of dialysate calcium concentration in hemodialysis. Hemodial Int 2006;10:326-37.

38. Kalantar-Zadeh K, Kopple JD. Trace elements and vitamins in maintenance dialysis patients. Adv Chronic Kidney Dis 2003;10(3):170-82.

39. Locatelli F, Fouque D, Heimburger O. Nutritional status in dialysis patients: a European consensus. Nephrol Dial Transplant 2002;17(4):563-72.

40. Ono K. Hypervitaminosis A toxicity in regular hemodialysis patients. Trans Am Soc Artif Intern Organs 1984;30:40-43.

41. Singh AK, Milford E, Fishbane S, Keithi Reddy SR. Managing anemia in dialysis patients: hemoglobin cycling and overshoot. Kidney Int 2008;74:679-83. 
42. Gülseven B, Oğuz S. Kronik durumlar. In: Karadakovan A, Eti Aslan F, editör. Dahili ve Cerrahi Hastalıklarda Bakım.2. Baskı. Adana: Nobel Kitapevi; 2011. s. 105-17.

43. Chilcot J, Wellsted D, Farrington K. Illness representations are associated with fluid nonadherence among hemodialysis patients. J Psychosom Res 2010;68:203-12.

44. Ahrari S, Moshki M, Bahrami M. The relationship between social support and adherence of dietary and fluids restrictions among hemodialysis patients in Iran. J Caring Sci 2014;3(1):11-9.
45. Scian B, Mariano J, Maluf J. Identification of biomarkers to assess organ quality and predict posttransplantation outcomes. Transplantation 2012;94(8):851-8.

46. Chan M, Chadban S. Nutritional management of kidney transplant recipients. Nutritional Management of Renal Disease 2013;2(1):563-80.

47. Martins R, Pecoits F, Riella MC. Nutrition for the post-renal transplant recipients. Transplant Proc. 2004;36(6):1650-4.

48. Nolte Fong JV, Moore LW. Nutrition trends in kidney transplant recipients: the importance of dietary monitoring and need for evidence-based recommendations. Front Med 2018;5: 302 doi: 10.3389/ fmed.2018.00302. 